\title{
Correction to: Prototypical Peripheral Toponym Pairs Expressing the Concept 'All Over the Country' as a Part of the Mental Map
}

\author{
Riemer Reinsma ${ }^{1}$
}

Published online: 12 December 2019

(c) The Author(s) 2019

\section{Correction to: \\ KN - Journal of Cartography and Geographic Information (2019) 69:229-250 \\ https://doi.org/10.1007/s42489-019-00027-x}

The article "Prototypical Peripheral Toponym Pairs Expressing the Concept 'All Over the Country' as a Part of the Mental Map", written by Riemer Reinsma, was originally published electronically on the publisher's internet portal on 20 August 2019 without open access.

With the author(s)' decision to opt for Open Choice, the copyright of the article changed in December 2019 to () The Author(s) 2019 and the article is forthwith distributed under the terms of the Creative Commons Attribution 4.0 International License (http://creativecommons.org/licenses/ by/4.0/), which permits use, sharing, adaptation, distribution and reproduction in any medium or format, as long as you give appropriate credit to the original author(s) and the source, provide a link to the Creative Commons license and indicate if changes were made.

The original article has been corrected.

Open Access This article is licensed under a Creative Commons Attribution 4.0 International License, which permits use, sharing, adaptation, distribution and reproduction in any medium or format, as long as you give appropriate credit to the original author(s) and the source, provide a link to the Creative Commons licence, and indicate if changes were made. The images or other third party material in this article are included in the article's Creative Commons licence, unless indicated otherwise in a credit line to the material. If material is not included in the article's Creative Commons licence and your intended use is not permitted by statutory regulation or exceeds the permitted use, you will need to obtain permission directly from the copyright holder. To view a copy of this licence, visit http://creativecommons.org/licenses/by/4.0/.

The original article can be found online at https://doi.org/10.1007/ s42489-019-00027-x.

Riemer Reinsma

rr@riemerreinsma.nl

http://www.riemerreinsma.nl/

1 Amsterdam, Netherlands 